\title{
Insights into the Effects of Simulated Nitrogen Deposition on Leaf Functional Traits of Rhus Typhina
}

\author{
Congyan Wang ${ }^{1 *}$, Hongguang Xiao', Jun Liu', \\ Jiawei Zhou', Daolin Du', 2** \\ ${ }^{1}$ Institute of Environment and Ecology, School of the Environment and Safety Engineering, Jiangsu University, \\ Zhenjiang 212013, P. R. China \\ ${ }^{2}$ Key Laboratory of Modern Agricultural Equipment and Technology, Ministry of Education and Jiangsu Province, \\ Jiangsu University, Zhenjiang 212013, P. R. China
}

Received: 3 January 2016

Accepted: 14 February 2016

\begin{abstract}
The effects of anthropogenic nitrogen $(\mathrm{N})$ deposition on successful plant invaders, particularly potential effects on their leaf functional traits, have stimulated considerable research interest. This study aims to gain insights into the leaf functional traits of the controversial invader Rhus typhina in the presence of a gradient of simulated $\mathrm{N}$ deposition (control, $0 \mathrm{~g} \mathrm{~L}^{-1}$; low $\mathrm{N}, 5 \mathrm{~g} \mathrm{~L}^{-1}$; medium $\mathrm{N}, 10 \mathrm{~g} \mathrm{~L}^{-1}$; and high $\mathrm{N}, 25 \mathrm{~g} \mathrm{~L}^{-1}$ ). Soil $\mathrm{pH}$ is decreased under the growth of $R$. typhina. The soil acidification mediated by $R$. typhina may be due to the positive effects of $R$. typhina on soil ammonium concentration and negative effects on soil nitrate concentration. Soil $\mathrm{pH}$ decreased under $\mathrm{N}$ fertilization due to the release of free $\mathrm{H}^{+}$via the nitrification process. Leaf width, leaf chlorophyll and $\mathrm{N}$ concentrations, SLA, and single leaf wet weight of $R$. typhina increased in the presence of all $\mathrm{N}$ fertilizers; medium $\mathrm{N}$ and high $\mathrm{N}$ fertilization also increased leaf length and leaf thickness of $R$. typhina due to the fertilizing effects of the addition of exogenous $\mathrm{N}$ on $R$. typhina growth. Thus, $R$. typhina leaves may possess higher resource capture ability as well as higher relative growth rate by reducing material investment per unit area under exogenous $\mathrm{N}$ fertilization. Meanwhile, medium $\mathrm{N}$ fertilization exerts stronger fertilizing effects on leaf length, leaf width, leaf chlorophyll and $\mathrm{N}$ concentrations, single leaf wet weight, and leaf thickness of $R$. typhina than those of high $\mathrm{N}$ fertilization. This is possibly because excess $\mathrm{N}$ fertilization could drive some unexpected reverse phenomena on leaf growth of $R$. typhina. Thus, leaf growth of $R$. typhina may be presumably attenuated with increasing amounts of anthropogenic $\mathrm{N}$ deposited into ecosystems in the future, and thereby pose pronounced effects on its subsequent further invasion.
\end{abstract}

Keywords: leaf functional traits, SLA, nitrogen deposition, Rhus typhina

*e-mail: liuyuexue623@163.com

**e-mail: ddl@ujs.edu.cn 


\section{Introduction}

Anthropogenic activities, such as the combustion of fossil fuels, the production and consumption of chemical nitrogen $(\mathrm{N})$ fertilizers, and the rapid development of animal husbandry, have triggered a global process that increases atmospheric $\mathrm{N}$ deposited into terrestrial ecosystems [1-3]. East Asia (mainly China), Western Europe, and North America are currently the major areas of $\mathrm{N}$ deposition [1, 3-4]. $\mathrm{N}$ deposition can incur changes in ecosystem functions, such as changes in soil $\mathrm{pH}$ values, soil microbial community and functioning, plant litter decomposition [5-8], and plant growth and physiological performance [9-10]. Meanwhile, invasive plants have also triggered serious impacts on native ecosystems on a global scale, especially affecting the structure and function of the ecosystems in which these invasions occur [11-12].

Many studies have confirmed that certain plants successfully invade certain ecosystems because leaf functional traits [such as higher specific leaf area (SLA)] of those invaders can enable them to acquire an advantage in resource capture and growth rate [13-14]. Generally, leaves with high SLA values were typically associated with high resource acquisition and use efficiency with low investment in leaf construction and protective tissues than those leaves with low SLA values [15-17]. Moreover, leaf size (indicated by leaf length and leaf width), leaf chlorophyll and $\mathrm{N}$ concentrations, single leaf wet weight, and leaf thickness are also pivotal indices of leaf functional traits because those indices are also known to be good indicators of resource-use strategy of plant species $[15$, 18-20]. Based on this, the effects of anthropogenic $\mathrm{N}$ deposition on successful invaders have raised considerable interest, particularly with respect to its potential effects on the leaf functional traits of invasive species to enucleate the mechanism underlying their successful ecological strategy.

This study aims to gain insights into the changes in leaf functional traits of the controversial invader Rhus typhina in the presence of a gradient of simulated $\mathrm{N}$ deposition (control, $0 \mathrm{~g} \mathrm{~L}^{-1}$; low $\mathrm{N}, 5 \mathrm{~g} \mathrm{~L}^{-1}$; medium $\mathrm{N}$, $10 \mathrm{~g} \mathrm{~L}^{-1}$; and high $\left.\mathrm{N}, 25 \mathrm{~g} \mathrm{~L}^{-1}\right)$. R. typhina is a deciduous tree native to North America and introduced to China as a main forestation species by the Botanical Garden, Institute of Botany, the Chinese Academy of Sciences in 1959 [2122]. This species has some ornamental values because of its fruit clusters (which look like burning torches in late summer and early autumn) and its brilliant red leaves in mid-autumn [21]. Unfortunately, this species can display somewhat invasive characteristics, such as sturdy growth and quick reproduction [21, 23]. Furthermore, this species has been scattered on almost all habitats from downtown to mountains, including roadsides, farmlands, and protected areas in many regions of China [21]. Therefore, R. typhina has been identified as a destructive invader by many botanists [21, 24]. In this present study, leaf functional traits (i.e., leaf size, leaf chlorophyll and $\mathrm{N}$ concentrations, SLA, single leaf wet weight, and leaf thickness) of $R$. typhina under a gradient of $\mathrm{N}$ fertilization are assessed to gain insight into its ecological strategy.
The results of this present study could provide a platform to better understand the successful strategy mechanisms of $R$. typhina and then lay an essential theoretical foundation and practical significance for effective invasion prevention and control, especially under conditions with increasing amounts of anthropogenic $\mathrm{N}$ deposited into ecosystems in the future. This study presents the following hypotheses. First, $R$. typhina can increase soil $\mathrm{pH}$ [25-26] because of the preferences of plant $\mathrm{N}$ required [27-28] and/or the alkaline substances in the litters and/or root exudations of invasive species [28-29]. Second, soil $\mathrm{pH}$ decreased under $\mathrm{N}$ fertilization [6-8] due to the release of free $\mathrm{H}^{+}$via the nitrification process under $\mathrm{N}$ fertilization [30-31]. Third, $\mathrm{N}$ fertilization could increase the values of leaf functional traits of $R$. typhina because $\mathrm{N}$ supply could enhance the growth and physiological performance of plant species $[9-10,15,32]$

\section{Materials and Methods}

\section{Experimental Design}

Root samples of $R$. typhina were collected mid-August 2015 in Jinan, P. R. China $\left(36.63^{\circ} \mathrm{N}, 117.03^{\circ} \mathrm{E}\right)$, which has a warm temperate climate. The annual mean temperature of the area is approximately $13.8^{\circ} \mathrm{C}$, annual precipitation is approximately $614 \mathrm{~mm}$, and the rainy season comes in June and July. All root samples were transported into planting pots as soon as possible using nutritious soils.

A mixed $\mathrm{N}$ solution was prepared with a $1: 1: 1$ ratio of $\mathrm{KNO}_{3}-\mathrm{N}: \mathrm{NH}_{4} \mathrm{Cl}-\mathrm{N}$ :urea-N. The ratio of different $\mathrm{N}$ forms in the mixed $\mathrm{N}$ was similar to the global average ratio of natural atmospheric $\mathrm{N}$ deposition [33-34]. The concentrations were made with distilled water prior to use to create a series with gradient contents, namely CK (control, $\left.0 \mathrm{~g} \mathrm{~L}^{-1}\right)$, low $\mathrm{N}\left(5 \mathrm{~g} \mathrm{~L}^{-1}\right)$, medium $\mathrm{N}\left(10 \mathrm{~g} \mathrm{~L}^{-1}\right)$, and high $\mathrm{N}\left(25 \mathrm{~g} \mathrm{~L}^{-1}\right)$. Three replicates were performed per treatment. The samples were incubated in a greenhouse at $25^{\circ} \mathrm{C}$ for approximately $70 \mathrm{~d}$. During the incubation, deionized water or simulated $\mathrm{N}$ fertilizers were supplied weekly according to the amount of precipitation in the study site.

\section{Determining Plant Characteristics}

The leaf length is the maximum value along the midrib, while the width is the maximum value perpendicular to the midrib [19-20, 35]. Leaf length and leaf width were measured using a ruler [19-20].

The relative chlorophyll and $\mathrm{N}$ concentrations in the leaves were estimated with a handheld plant nutrient meter (TYS-3N, China). TYS-3N was used to calculate the index in "SPAD units" based on absorbance at $650 \mathrm{~nm}$ and $940 \mathrm{~nm}$.

SLA was computed using the ratio of the leaf area to the corresponding leaf dry weight $\left(\mathrm{cm}^{2} \mathrm{~g}^{-1}\right)$ according to previous studies [16, 19-20]. 


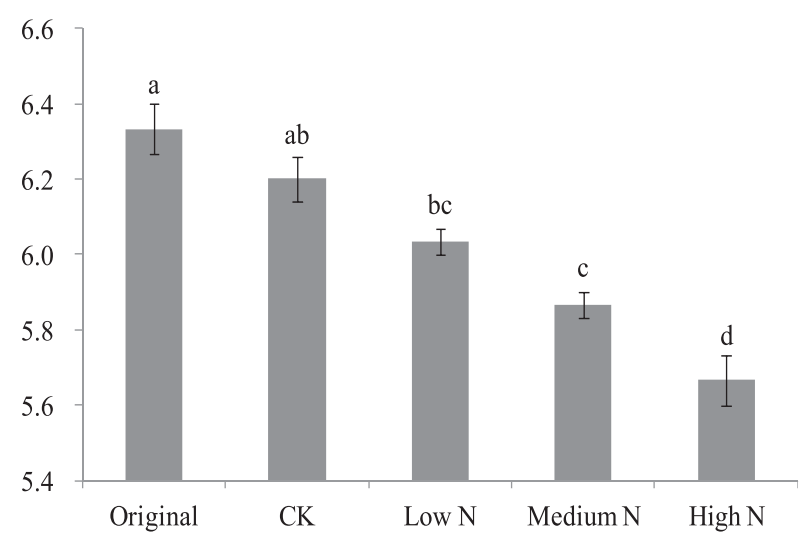

Fig. 1. Differences in soil $\mathrm{pH}$ values under different treatments. Data with different letters indicate a significant difference $(P<$ $0.05)$.

Single leaf wet weight was determined using an electronic balance with an accuracy of $0.001 \mathrm{~g}$ [19-20].

Leaf thickness was calculated through the overlap of five leaves using a Vernier caliper with an accuracy of 0.01 $\mathrm{mm}$ [19-20].

The $\mathrm{pH}$ values of original nutrition soil samples and those under growth of $R$. typhina were all measured using a soil acidity meter in situ (ZD instrument - ZD-06, P. R. China) [19].

\section{Statistical Analysis}

Data were evaluated to determine the deviations from normality and homogeneity of variance before data analysis. Differences among various dependent variables were assessed using analysis of variance. Statistically significant differences were set at $P$ values equal to or lower than 0.05 . Correlation patterns among various dependent variables were determined by correlation analysis using IBM SPSS Statistics (version 22.0).

\section{Results}

Soil $\mathrm{pH}$ decreased under the growth of $R$. typhina but not substantially (Fig. $1, P>0.05$ ). Soil $\mathrm{pH}$ decreased under all $\mathrm{N}$ fertilization (Fig. 1) and significantly decreased under medium $\mathrm{N}$ and high $\mathrm{N}$ fertilization (Fig. $1, P<0.05)$.

Leaf width, leaf chlorophyll and $\mathrm{N}$ concentrations $(P>0.05)$, and single leaf wet weight $(P<0.05)$ of $R$. typhina were in the order of medium $\mathrm{N}>$ high $\mathrm{N}>$ low $\mathrm{N}>\mathrm{CK}$ (Table 1). Medium $\mathrm{N}$ and high $\mathrm{N}$ fertilization increased leaf length and leaf thickness of $R$. typhina and medium $\mathrm{N}$ displayed greater effects than those of high $\mathrm{N}$ fertilization, but this change was not pronounced (Table 1, $P>0.05)$. SLA increased with increasing concentrations of $\mathrm{N}$ fertilizers (Table 1, $P>0.05$ ).

Correlation patterns among leaf functional traits of $R$. typhina were observed through correlation analysis (Table 2). In particular, leaf length was positively correlated with leaf width, single leaf wet weight, and leaf thickness (Table 2, $P<0.001$ ). Leaf width was positively correlated with single leaf wet weight and leaf thickness (Table 2, $P<0.01$ ). Leaf chlorophyll concentration was positively correlated with leaf $\mathrm{N}$ concentration (Table 2, $P<0.0001)$. Single leaf wet weight was positively correlated with leaf thickness (Table 2, $P<0.001$ ).

\section{Discussion}

Previous studies showed that invasive species could increase soil $\mathrm{pH}$ [25-26] because of the preferences of plant $\mathrm{N}$ required [27-28], and/or the alkaline substances in the litters and/or root exudations of invasive species [2829]. Soil pH decreased under the growth of $R$. typhina, although not substantially in this study (Fig. 1). This result is inconsistent with our hypothesis and with the results of previous studies [25-26]. The soil acidification mediated by $R$. typhina may be due to the positive effects on soil ammonium concentration and negative affects on soil nitrate concentration [34]. Similar results were also revealed in other studies [29, 37-38].

It can be speculated that the decreased soil $\mathrm{pH}$ values mediated by invasive species could enhance phosphor (P) solubility in soil [39-40], and higher $\mathrm{P}$ availability could facilitate further encroachment by invasive species [39, 41]. Previous studies also have reported some inconsistent results of the effects of invasive species on soil $\mathrm{pH}$. For example, some studies founded that invasive species could trigger soil acidification [29, 36-38]. Si et al. [11]

Table 1. Differences in leaf functional traits of R. typhina under different treatments. Data with different letters in a vertical row indicate a significant difference $(P<0.05)$. "ns" means not significant difference $(P>0.05)$. Abbreviations: LL, leaf length $(\mathrm{cm})$; LW, leaf width $(\mathrm{cm})$; LCC, leaf chlorophyll concentration (SPAD); LNC, leaf $\mathrm{N}$ concentration ( $\left.\mathrm{mg} \mathrm{g}^{-1}\right)$; SLA, specific leaf area $\left(\mathrm{cm}^{2} \mathrm{~g}^{-1}\right)$; SLWW, single leaf wet weight; LT, leaf thickness (mm).

\begin{tabular}{|c|c|c|c|c|c|c|c|}
\hline & LL & LW & LCC & LNC & SLA & SLWW & LT \\
\hline CK & $5.50 \pm 0.28 \mathrm{~ns}$ & $1.64 \pm 0.05 \mathrm{~ns}$ & $38.99 \pm 2.45 \mathrm{~ns}$ & $3.30 \pm 0.17 \mathrm{~ns}$ & $422.23 \pm 63.64 \mathrm{~ns}$ & $0.03 \pm 0.00 \mathrm{~b}$ & $0.20 \pm 0.01 \mathrm{~ns}$ \\
\hline Low N & $5.37 \pm 0.64 \mathrm{~ns}$ & $1.79 \pm 0.16 \mathrm{~ns}$ & $39.89 \pm 0.68 \mathrm{~ns}$ & $3.37 \pm 0.05 \mathrm{~ns}$ & $458.07 \pm 37.50 \mathrm{~ns}$ & $0.04 \pm 0.01 \mathrm{ab}$ & $0.20 \pm 0.01 \mathrm{~ns}$ \\
\hline Medium N & $6.87 \pm 1.07 \mathrm{~ns}$ & $2.26 \pm 0.24 \mathrm{~ns}$ & $41.01 \pm 0.38 \mathrm{~ns}$ & $3.43 \pm 0.03 \mathrm{~ns}$ & $477.18 \pm 25.47 \mathrm{~ns}$ & $0.08 \pm 0.02 \mathrm{a}$ & $0.27 \pm 0.03 \mathrm{~ns}$ \\
\hline High N & $6.54 \pm 0.20 \mathrm{~ns}$ & $1.89 \pm 0.18 \mathrm{~ns}$ & $40.78 \pm 0.15 \mathrm{~ns}$ & $3.41 \pm 0.01 \mathrm{~ns}$ & $588.50 \pm 27.05 \mathrm{~ns}$ & $0.07 \pm 0.01 \mathrm{ab}$ & $0.23 \pm 0.01 \mathrm{~ns}$ \\
\hline
\end{tabular}


Table 2. Relationship among leaf functional traits of R. typhina. ** and *** indicate significant differences at 0.01 and 0.001 probability levels, respectively. Abbreviations have the same meanings as described in Table 1.

\begin{tabular}{|c|c|c|c|c|c|c|c|c|}
\hline & & LL & LW & LCC & LNC & SLA & SLWW & LT \\
\hline \multirow{2}{*}{ LL } & $\mathrm{r}$ & 1.00 & $0.83 * * *$ & 0.00 & -0.01 & 0.48 & $0.83 * * *$ & $0.85 * * *$ \\
\hline & $P$ & & 0.0008 & 0.9925 & 0.9862 & 0.1133 & 0.0008 & 0.0005 \\
\hline \multirow{2}{*}{ LW } & $\mathrm{r}$ & & 1.00 & 0.13 & 0.11 & 0.30 & $0.75 * *$ & $0.89 * * *$ \\
\hline & $P$ & & & 0.6788 & 0.7363 & 0.3412 & 0.0050 & 0.0001 \\
\hline \multirow{2}{*}{ LCC } & $\mathrm{r}$ & & & 1.00 & $1.00 * *$ & -0.11 & 0.39 & 0.14 \\
\hline & $P$ & & & & $<0.0001$ & 0.7319 & 0.2120 & 0.6542 \\
\hline \multirow{2}{*}{ LNC } & $\mathrm{r}$ & & & & 1.00 & -0.13 & 0.39 & 0.13 \\
\hline & $P$ & & & & & 0.6766 & 0.2146 & 0.6982 \\
\hline \multirow{2}{*}{ SLA } & $\mathrm{r}$ & & & & & 1.00 & 0.48 & 0.45 \\
\hline & $P$ & & & & & & 0.1123 & 0.1455 \\
\hline \multirow{2}{*}{ SLWW } & $r$ & & & & & & 1.00 & $0.86 * * *$ \\
\hline & $P$ & & & & & & & 0.0003 \\
\hline \multirow{2}{*}{ LT } & $\mathrm{r}$ & & & & & & & 1.00 \\
\hline & $P$ & & & & & & & \\
\hline
\end{tabular}

also founded that low-cover classes of the invasive plant Wedelia trilobata significantly increase soil $\mathrm{pH}$, but highcover classes do not affect soil pH significantly. Thus, the effects of invasive species on soil $\mathrm{pH}$ may vary by species and the difference in the effects of plant invasion on soil $\mathrm{pH}$ may be mainly due to the difference in the chemical composition of the leaching substances of plant litters and root exudates.

Evidence suggests that the addition of $\mathrm{N}$ fertilizers contributes to soil acidification due to the release of free $\mathrm{H}^{+}$ through the nitrification process, which results in a gradual decrease of soil $\mathrm{pH}$ [30-31]. This study also showed that soil $\mathrm{pH}$ decreased in the presence of all $\mathrm{N}$ fertilizers (Fig. $1)$. The result is consistent with our hypothesis and those reported in previous studies [6-8].

$\mathrm{N}$ has been found to be the most essential factor that determines plant growth [42]. Thus, plants can present stimulated growth and physiological performance under elevated $\mathrm{N}$ supply mainly via eliminating $\mathrm{N}$ deficiency [9-10]. Generally, N fertilization could increase leaf size, leaf chlorophyll and $\mathrm{N}$ concentrations, and SLA [15, 32]. This study also revealed that leaf width, leaf chlorophyll and $\mathrm{N}$ concentrations, SLA, and single leaf wet weight of $R$. typhina increased in the presence of all $\mathrm{N}$ fertilizers; medium $\mathrm{N}$ and high $\mathrm{N}$ also increased leaf length and leaf thickness of $R$. typhina (Table 1). The result is consistent with our hypothesis and previous studies $[15,32]$. This implied that $R$. typhina leaves may possess higher resource capture ability as well as higher relative growth rate with reduce material investment per unit area under exogenous $\mathrm{N}$ fertilization. Hence, $\mathrm{N}$ fertilization could exert a fertilizing effect on the growth $R$. typhina in this study. It is worth noting that medium $\mathrm{N}$ fertilization exerts stronger fertilizing effects on leaf length, leaf width, leaf chlorophyll and $\mathrm{N}$ concentrations, single leaf wet weight, and leaf thickness of $R$. typhina than those of high $\mathrm{N}$ fertilization in this study (Table 1). The possible reason for this is that excess $\mathrm{N}$ fertilization could drive some unexpected reverse phenomena that could reduce the stimulation of exogenous $\mathrm{N}$ supply on plant growth [4344], mainly via the enhanced soil acidification, although moderate $\mathrm{N}$ addition could enhance plant growth by eliminating $\mathrm{N}$ deficiency [9-10]. Thus, leaf growth of $R$. typhina may presumably be attenuated with increasing amounts of anthropogenic $\mathrm{N}$ deposited into ecosystems in the future, and thereby pose pronounced effects on its further invasion subsequently.

Numerous studies have shown that leaf size was positively correlated with SLA because leaves with high SLA provide low structural investment, but leaves with low SLA likely allocate more biomass on leaf structures [15, 17-18]. However, SLA was unrelated to other leaf traits (including leaf size) significantly in this study (Table 2 ). This result is inconsistent with previous studies $[15,17$ 18]. Previous studies also have reported some inconsistent results of the correlations between leaf size and SLA, including positive [45], negative [20, 46], unrelated [19, 47], or variable among habitats [48]. Based on this, we believe that there is species specificity for the relationship among leaf functional traits. The main aim of this study was to investigate the effects of a gradient of simulated $\mathrm{N}$ deposition on leaf functional traits of the controversial invader R. typhina.

$R$. typhina can trigger soil acidification, possibly due to the positive effects of $R$. typhina on soil ammonium concentration and negative affects on soil nitrate 
concentration. $\mathrm{N}$ fertilization can mediate a reduction in soil $\mathrm{pH}$ due to the release of free $\mathrm{H}^{+}$via the nitrification process. All $\mathrm{N}$ fertilizers have a fertilizing effect on leaf width, leaf chlorophyll and $\mathrm{N}$ concentrations, SLA, and single leaf wet weight of $R$. typhina. Meanwhile, medium $\mathrm{N}$ and high $\mathrm{N}$ fertilization also display positive effects on leaf length and leaf thickness of $R$. typhina. This implies that $R$. typhina leaves may possess higher resource capture ability as well as a higher relative growth rate by reducing material investment per unit area under exogenous $\mathrm{N}$ fertilization. Then again, medium $\mathrm{N}$ fertilization exerts stronger fertilizing effects on leaf length, leaf width, leaf chlorophyll and $\mathrm{N}$ concentrations, single leaf wet weight, and leaf thickness of $R$. typhina than those of high $\mathrm{N}$ fertilization. The phenomenon may be caused by the unexpected reverse phenomena on leaf growth of $R$. typhina mediated by excess $\mathrm{N}$ fertilization. Based on this, leaf growth of $R$. typhina may be presumably attenuated with increasing amounts of anthropogenic $\mathrm{N}$ deposited into ecosystems in the future, and thereby pose pronounced effects on its further invasion.

\section{Acknowledgements}

This study was supported by the National Natural Science Foundation of China (31300343, 31570414), the Natural Science Foundation of Jiangsu Province, China (BK20130500), the Universities Natural Science Research Project of Jiangsu Province, China (13KJB610002), the Jiangsu Collaborative Innovation Center of Technology and Material of Water Treatment, and Research Foundation for Advanced Talents, Jiangsu University (12JDG086). We are grateful to the anonymous reviewer for the insightful and constructive comments that greatly improved this manuscript.

\section{References}

1. GALLOWAY J.N., DENTENER F.J., CAPONE D.G., BOYER E.W., HOWARTH R.W., SEITZINGER S.P., ASNER G.P., CLEVELAND C.C., GREEN P.A., HOLLAND E.A., KARL D.M., MICHAELS A.F., PORTER J.H., TOWNSEND A.R., VOROSMARTY C.J. Nitrogen cycles: past, present, and future. Biogeochemistry. 70, 153, 2004.

2. GALLOWAY J.N., TOWNSEND A.R., ERISMAN J.W., BEKUNDA M., CAI Z., FRENEY J.R. MARTINELLI L.A., SEITZINGER S.P., SUTTON M.A. Transformation of the nitrogen cycle: Recent trends, questions, and potential solutions. Science. 320, 889, 2008.

3. LIU X.J., ZHANG Y., HAN W.X., TANG A.H., SHEN J.L., CUI Z.L., VITOUSEK P., ERISMAN J.W., GOULDING K., CHRISTIE P., FANGMEIER A., ZHANG F.S. Enhanced nitrogen deposition over China. Nature. 494, 459, 2013

4. WANG T.J., JIANG F., LI S., LIU Q. Trends in air pollution during 1996-2003 and cross-border transport in city clusters over the Yangtze River Delta region of China. Terr. Atmos. Ocean. Sci. 18, 995, 2007.

5. WANG C.Y., FENG X.G., GUO P., HAN G.M., TIAN
X.J. Response of degradative enzymes to $\mathrm{N}$ fertilization during litter decomposition in a subtropical forest through a microcosm experiment. Ecol. Res. 25, 1121, 2010.

6. WANG C.Y., HAN G.M., JIA Y., FENG X.G., GUO P., TIAN X.J. Response of litter decomposition and related soil enzyme activities to different forms of nitrogen fertilization in a subtropical forest. Ecol. Res. 26, 505, 2011.

7. LV Y.N., WANG C.Y., JIA Y.Y., DU J.J., MA X., WANG W.W., PU G.Z., TIAN X.J. Responses of soil microbial biomass and enzymatic activities to different forms of organic nitrogen deposition in the subtropical forest in East China. Ecol. Res. 28, 447, 2013.

8. LV Y.N., WANG C.Y., WANG F.Y., ZHAO G.Y., PU G.Z., MA X., TIAN X.J. Effects of nitrogen addition on litter decomposition, soil microbial biomass, and enzyme activities between leguminous and non-leguminous forests. Ecol. Res. 28, 793, 2013.

9. LEBAUER D.S., TRESEDER K.K. Nitrogen limitation of net primary productivity in terrestrial ecosystems is globally distributed. Ecology. 89, 371, 2008.

10. VILLAR-SALVADOR P., PEÑUELAS J.L., NICOLÁSPERAGÓN J.L., BENITO L.F., DOMÍNGUEZ-LERENA $\mathrm{S}$. Is nitrogen fertilization in the nursery a suitable tool for enhancing the performance of Mediterranean oak plantations? New Forest. 44, 733, 2013.

11. SI C.C., LIU X.Y., WANG C.Y., WANG L., DAI Z.C., QI S.S., DU D.L. Different degrees of plant invasion significantly affect the richness of the soil fungal community. PLoS ONE. 8, e85490, 2013.

12. WANG C.Y., XIAO H.G., LIU J., WANG L., DU D.L. Insights into ecological effects of invasive plants on soil nitrogen cycling. Am. J. Plant Sci. 6, 34, 2015.

13. VAN KLEUNEN M., WEBER E., FISCHER M. A metaanalysis of trait differences between invasive and noninvasive plant species. Ecol. Lett. 13, 235, 2010.

14. TE BEEST M., ESLER K.J., RICHARDSON D.M. Linking functional traits to impacts of invasive plant species: a case study. Plant Ecol. 216, 293, 2015.

15. WRIGHT I.J., ACKERLY D.D., BONGERS F., HARMS K.E., IBARRA-MANRIQUEZ G., MARTINEZ-RAMOS M., MAZER S.J., MULLER-LANDAU H.C., PAZ H., PITMAN N.C.A., POORTER L., SILMAN M.R., VRIESENDORP C.F., WEBB C.O., WESTOBY M., WRIGHT S.J. Relationships among ecologically-important dimensions of plant trait variation in seven neotropical forests. An. Bot. 99, 1003, 2007.

16. SCHEEPENS J.F., FREI E.S., STÖCKLIN J. Genotypic and environmental variation in specific leaf area in a widespread Alpine plant after transplantation to different altitudes. Oecologia. 164, 141, 2010.

17. PIETSCH K.A., OGLE K., CORNELISSEN J.H.C., CORNWELL W.K., BÖNISCH G., CRAINE J.M., JACKSON B.G., KATTGE J., PELTZER D.A., PENUELAS J., REICH P.B., WARDLE D.A., WEEDON J.T., WRIGHT I.J., ZANNE A.E., WIRTH C. Global relationship of wood and leaf litter decomposability: the role of functional traits within and across plant organs. Global Ecol. Biogeogr. 23, 1046, 2014.

18. SOUDZILOVSKAIA N.A., ELUMEEVA T.G., ONIPCHENKO V.G., SHIDAKOV I.I., SALPAGAROVA F.S., KHUBIEV A.B., TEKEEV D.K., CORNELISSEN J.H.C. Functional traits predict relationship between plant abundance dynamic and long-term climate warming. P. Natl. Acad. Sci. U.S.A. 110, 18180, 2013.

19. XIAOH.G., WANG C.Y., LIU J., WANG L., DU D.L. Insights into the differences in leaf functional traits of heterophyllous 
Syringa oblata under different light intensities. J. For. Res. 26, 613, 2015.

20. WANG C.Y., LIU J., XIAO H.G., DU D.L. Response of leaf functional traits of Cerasus yedoensis (Mats.) Yü li to serious insect attack. Pol. J. Environ. Stud. 25, 333, 2016.

21. WANG G., JIANG G., YU S., LI Y., LIU H. Invasion possibility and potential effects of Rhus typhina on Beijing Municipality. J. Integr. Plant Biol. 50, 522, 2008.

22. YUAN Y.F., GUO W.H., DING W.J., DU N., LUO Y.J., LIU J., XU F., WANG R.Q. Competitive interaction between the exotic plant Rhus typhina L. and the native tree Quercus acutissima Carr. in Northern China under different soil N: P ratios. Plant Soil. 372, 389, 2013.

23. ZHANG Z.J., JIANG C.D., ZHANG J.Z., ZHANG H.J., SHI L. Ecophysiological evaluation of the potential invasiveness of Rhus typhina in its non-native habitats. Tree Physiol. 29, 1307, 2009.

24. WEBER E., SUN S.Q., LI B. Invasive alien plants in China: diversity and ecological insights. Biol. Invasions. 10, 1411, 2008.

25. FAN L., CHEN Y., YUAN J.G., YANG Z.Y. The effect of Lantana camara Linn. invasion on soil chemical and microbiological properties and plant biomass accumulation in southern China. Geoderma. 154, 370, 2010.

26. KUEBBING S.E., CLASSEN A.T., SIMBERLOFF D. Two co-occurring invasive woody shrubs alter soil properties and promote subdominant invasive species. J. Appl. Ecol. 51, $124,2014$.

27. EHRENFELD J.G. Effects of exotic plant invasions on soil nutrient cycling processes. Ecosystems. 6, 503, 2003.

28. CHEN T., LIU W.L., ZHANG C.B., WANG J. Effects of Solidago canadensis invadation on dynamics of native plant communities and their mechanisms. Chin. J. Plant Ecol. 36, 253, 2012. (In Chinese)

29. DASSONVILLE N., GUILLAUMAUD N., PIOLA F., MEERTS P., POLY F. Niche construction by the invasive Asian knotweeds (species complex Fallopia): impact on activity, abundance and community structure of denitrifiers and nitrifiers. Biol. Invasions. 13, 1115, 2011.

30. TU L.H., CHEN G., PENG Y., HU H.L., HU T.X., ZHANG J., LI X.W., LIU L., TANG Y. Soil biochemical responses to nitrogen addition in a bamboo forest. PLoS ONE. 9, e102315, 2014

31. GAO W., YANG H., KOU L., LI S. Effects of nitrogen deposition and fertilization on $\mathrm{N}$ transformations in forest soils: a review. J. Soil. Sediment. 15, 863, 2015.

32. PELLISSIER L., WISZ M.S., STRANDBERG B., DAMGAARD C. Herbicide and fertilizers promote analogous phylogenetic responses but opposite functional responses in plant communities. Environ. Res. Lett. 9, 024016, 2014.

33. NEFF J.C., HOLLAND E.A., DENTENER F.J., MCDOWELL W.H., RUSSELL K.M. The origin, composition and rates of organic nitrogen deposition: a missing piece of the nitrogen cycle? Biogeochemistry. 57, 99, 2002.

34. CORNELL S.E., JICKELLS T.D., CAPE J.N., ROWLAND A.P., DUCE R.A. Organic nitrogen deposition on land and coastal environments: a review of methods and data. Atmos. Environ. 37, 2173, 2003.
35. WANG Z., ZHANG L. Leaf shape alters the coefficients of leaf area estimation models for Saussurea stoliczkai in central Tibet. Photosynthetica. 50, 337, 2012.

36. HAWKES C.V., WREN I.F., HERMAN D.J., FIRESTONE M.K. Plant invasion alters nitrogen cycling by modifying the soil nitrifying community. Ecol. Lett. 8, 976, 2005.

37. LAZZARO L., GIULIANI C., FABIANIA., AGNELLI A.E., PASTORELLI R., LAGOMARSINO A., BENESPERI R., CALAMASSI R., FOGGI B. Soil and plant changing after invasion: The case of Acacia dealbata in a Mediterranean ecosystem. Sci. Total Environ. 497-498, 491, 2014.

38. NOVOA A., RODRÍGUEZ R., RICHARDSON D., GONZÁLEZ L. Soil quality: a key factor in understanding plant invasion? The case of Carpobrotus edulis (L.) NE Br. Biol. Invasions. 16, 429, 2014.

39. HERR C., CHAPUIS-LARDY L., DASSONVILLE N., VANDERHOEVEN S., MEERTS P. Seasonal effect of the exotic invasive plant Solidago gigantea on soil $\mathrm{pH}$ and $\mathrm{P}$ fractions. J. Plant Nutr. Soil Sci. 170, 729, 2007.

40. ZHANG G.N., CHEN Z.H., ZHANG A.M., CHEN L.J., WU Z.J. Influence of climate warming and nitrogen deposition on soil phosphorus composition and phosphorus availability in a temperate grassland, China. J. Arid Land. 6, 156, 2014.

41. WEIDENHAMER J.D., CALLAWAY R.M. Direct and indirect effects of invasive plants on soil chemistry and ecosystem function. J. Chem. Ecol. 36, 59, 2010.

42. PENG Y.H., NIKLAS K.J., SUN S.C. The relationship between relative growth rate and whole-plant $\mathrm{C}: \mathrm{N}: \mathrm{P}$ stoichiometry in plant seedlings grown under nutrientenriched conditions. J. Plant Ecol. 4, 147, 2011.

43. FANG Y.T., GUNDERSEN P., MO J.M., ZHU W.X. Nitrogen leaching in response to increased nitrogen inputs in subtropical monsoon forests in southern China. Forest Ecol. Manag. 257, 332, 2009.

44. FIELD C.D., DISE N.B., PAYNE R.J., BRITTON A.J., EMMETT B.A., HELLIWELL R.C., HUGHES S., JONES L., LEES S., LEAKE J.R., LEITH I.D., PHOENIX G.K., POWER S.A., SHEPPARD L.J., SOUTHON G.E., STEVENS C.J., CAPORN S.J.M. The role of nitrogen deposition in widespread plant community change across semi-natural habitats. Ecosystems. 17, 864, 2014.

45. BURNS K.C., BEAUMONT S.A.M. Scale-dependent trait correlations in a temperate tree community. Austral Ecol. 34, 670, 2009.

46. NIKLAS K.J., COBB E.D., NIINEMETS Ü., REICH P.B., SELLIN A., SHIPLEY B., WRIGHT I.J. "Diminishing returns" in the scaling of functional leaf traits across and within species groups. P. Natl. Acad. Sci. U.S.A. 104, 8891, 2007.

47. WRIGHT I.J., ACKERLY D.D., BONGERS F., HARMS K.E., IBARRA-MANRIQUEZ G., MARTINEZ-RAMOS M., MAZER S.J., MULLER-LANDAU H.C., PAZ H, PITMAN N.C.A., POORTER L., SILMAN M.R., VRIESENDORP C.F., WEBB C.O., WESTOBY M., WRIGHT S.J. Relationships among ecologically-important dimensions of plant trait variation in seven neotropical forests. An. Bot. 99, 1003, 2007.

48. PICKUP M., WESTOBY M., BASDEN A. Dry mass costs of deploying leaf area in relation to leaf size. Funct. Ecol. 19, 88, 2005. 